Research Paper

\title{
Clinical and mycological analysis of dog's oral cavity
}

\author{
Rosema Santin ${ }^{1}$, Antonella Souza Mattei ${ }^{1}$, Stefanie Bressan Waller ${ }^{1}$, \\ Isabel Martins Madrid ${ }^{1}$, Marlete Brum Cleff ${ }^{2}$, Melissa Orzechowski Xavier², \\ Márcia de Oliveira Nobre ${ }^{2}$, Patrícia da Silva Nascente ${ }^{4}$, João Roberto Braga de Mello ${ }^{5}$, \\ Mário Carlos Araújo Meireles ${ }^{1}$ \\ ${ }^{1}$ Centro de Diagnóstico e Pesquisa em Micologia Veterinária, Departamento de Veterinária Preventiva, \\ Universidade Federal de Pelotas, Pelotas, RS, Brazil. \\ ${ }^{2}$ Departamento de Clínicas Veterinária, Universidade Federal de Pelotas, Pelotas, RS, Brazil. \\ ${ }^{3}$ Faculdade de Medicina, Universidade Federal do Rio Grande, Rio Grande, RS, Brazil. \\ ${ }^{4}$ Departamento de Microbiologia e Parasitologia, Instituto de Biologia, Universidade Federal de Pelotas, \\ Pelotas, RS, Brazil. \\ ${ }^{5}$ Departamento de Farmacologia, Instituto de Ciências Básicas da Saúde, Universidade Federal do Rio \\ Grande do Sul, Porto Alegre, RS, Brazil.
}

Submitted: July 24, 2011; Approved: July 2, 2012.

\begin{abstract}
The oral microbiota of humans and animals is made up of a wide variety of yeasts and bacteria, but microbiota of dogs is not totally described. Although such identification is an important step to establish the etiopathogenesis and adequate therapy for the periodontal disease The aim of this study was to evaluate and correlate oral alterations with the presence of yeasts in oral cavity of female dogs. After clinical evaluation samples from healthy and from dogs with oral diseases were obtained from three different oral sites by swabs, curettes, millimeter periodontal probes and HA membrane tip in cellulose ester. Yeast identification was performed through macroscopic and microscopic colony features and biochemical tests. Dental calculus was the most prevalent occurrence in the oral cavity of 59 females. However, the isolation of yeasts was significantly higher $(\mathrm{p}<0.05)$ in animals suffering from halitosis. Eleven yeast species were identified, namely: Malassezia pachydermatis, Rhodotorula spp., Candida albicans, C. catenulata, C. famata, C. guilliermondii, C. parapsilosis, C. intermedia, Trichosporon asahii, T. mucoides and Cryptococcus albidus. It could be concluded that the yeasts are part of the microbiota from the different sites of the oral cavity of the female canines studied without causing any significant alterations except halitosis.
\end{abstract}

Key words: oral microbiota. yeasts. M. pachydermatis. Candida spp.. halitosis.

\section{Introduction}

Trabulsi and Sampaio (2005) observed that the oral cavity microbiota of humans and animals is made up of a wide variety of yeasts and bacteria. As these microorganisms can be responsible for different oral affections and may as well be involved in systemic diseases, they identification has a fundamental importance in human dentistry and medicine. Braga et al. (2005) reported the identification of the major microorganisms with a pathogenic poten- tial in the oral cavity of animals also plays an important clinical role such as to provide support towards adequate diagnosis and therapy in veterinary medicine.

Cleff et al. (2007) mentioned that most yeasts mainly those of the Candida genus, make up the microbiota of healthy beings and are known to cause opportunistic mycoses all over the world. In dogs, yeasts preferably colonize moist areas such as mucous membranes, mucocutaneous junctions, skinfolds, interdigital areas and ears.

Send correspondence to R. Santin. Departamento de Veterinária Preventiva, Faculdade de Veterinária, Universidade Federal de Pelotas, Campus Universitário s/n, 96010-900 Pelotas, RS, Brazil. E-mail: seminhavet@yahoo.com.br. 
Few studies on yeast-like microbiota and the pathogenic potential of these agents in the oral cavity of dogs are available in the literature. Thus, the aim of this study was to evaluate and correlate oral alterations with yeasts isolation from different sites of canine oral cavity.

\section{Materials and Methods}

In order to do this study, 59 mongrel female canines of varying ages were used. The animals were referred to the Hospital de Clínicas Veterinária of the Universidade Federal de Pelotas (HCV-UFPel) for selective ovariohysterectomy. After their discharged from the surgical center, animals were randomly selected and all females were duly identified in medical records. A clinical examination and sample collecting for fungal culture from different sites in the oral cavity of the animals were done.

The clinical examination of the oral cavity was performed in anesthetized patients in the immediate postoperative period, previously to antimicrobial administration. The following variables were analyzed: dental calculus, dental fracture, malocclusion, halitosis and gingival bleeding occurrence. Then the periodontal sulcus was measured by the introduction of a millimeter periodontal (ABC Instrumentos Cirúrgicos LTDA, São Paulo, Brazil) probe through the buccal surface of the $4^{\text {th }}$ right upper premolar $\left(4^{\text {th }}\right.$ RUPM) and the upper left canine (ULC) of each animal.

Oral cavity samples were obtained from different sites, such as gingival mucosa, dental biofilm and periodontal sulcus. Material collecting from the gingival mucosa was done by sterile swab friction and scraping by a sterile curette, while the dental biofilm samples from the upper canine (left or right, randomly) were collected by sterile curette friction. In the periodontal sulcus collecting, two samples from both the $4^{\text {th }}$ RUPM and ULC teeth were obtained by a sterile millimeter periodontal probe and membrane tip (Millipore, Barueri, São Paulo, Brazil) which were introduced in the respective dental sulcus.

All samples were immediately cultivated on Sabouraud dextrose Agar (Acumedia, Lansing, Michigan, USA) added with chloramphenicol and olive oil, incubated at $36^{\circ} \mathrm{C}$ for up to a seven-day period, and accompanied daily. Edge, topography, color and texture were the macroscopic features evaluated from yeast-like colonies. Micromorphological identification was done by the Gram technique, followed by $100 \mathrm{X}$ objectives immersion visualization.

Another tests as growth in culture medium without the addition of long chain fatty acids to prove lipodependence, urease and catalase tests, as well as germ tube production in horse serum were also performed. Final identification, except for the Malassezia and Rhodotorula genera, was done by the ID 32C standardized system, bioMériux (ATB Expression ${ }^{\circledR}$, Marcy-l'Etoile, France) for yeasts.
Frequency analysis was performed by the Chi-Square test using the Statistix 8.0 software.

\section{Results}

In the oral cavity examination of 59 female dogs, dental calculus $(77.97 \%)$ was the most prevalent alteration found, followed by dental fractures $(30.51 \%)$, malocclusion $(23.73 \%)$ and gingival bleeding (11.86\%). A significant relation among these alterations and yeast isolation was not found; however, yeast isolation in halitosis-bearing animals $(85.7 \%)$ was significantly higher $(\mathrm{p}<0.05)$ than that in animals without halitosis $(46.2 \%)$.

The sulcus mean depth in the evaluated animals was $2 \mathrm{~mm}$; only two $4^{\text {th }}$ RUPM sulcus $(3.39 \%)$ and one ULC sulcus $(1.69 \%)$ had a depth over $3 \mathrm{~mm}$, and there was no yeast isolation in these cases.

Yeasts were isolated from $30(50.85 \%)$ animals. There was positive animal variation according to technique and site of collecting. Also, there was variation in number of isolates per animal: in 22 (37.29\%) only one microorganism was found and in eight (13.56\%), two or three yeasts were found.

Sixty-one yeasts isolates from different sites of oral cavity belonging to the Malassezia (50.8\%), Candida (14.7\%), Trichosporon (14.7\%), Rhodotorula (13.1\%) and Cryptopcoccus (6.6\%) genera were found. From these five genus, 11 species were identified, and the most frequently isolated yeast was $M$. pachydermatis, which was also the only yeast present in all studied sites. From the Candida genus, $C$. albicans, $C$. catenulata, $C$. famata, $C$. guilliermondii, C. parapsilosis and C. intermedia were the species identified; however, there was no growth of this genus in the biofilm and periodontal sulcus samples. Other yeasts such as Rhodotorula spp., T. asahii, T. mucoides and Cryptococcus albidus were isolated. C. albidus was isolated from the four different collecting procedures, but from only one animal. Fungal growth was obtained in all examined sites (Table 1).

\section{Discussion}

According to Braga et al. (2005), the knowledge of infectious agents in the oral cavity and the relation of these agents to oral diseases have been studied both in human medicine and dentistry. Nevertheless, in veterinary medicine, minor informations are known about microbiota microorganisms and their relation to periodontal disease, which responds for the greatest number of veterinary care.

Roza (2004) studied the high prevalence of yeast isolation in halitosis-bearing animals founded in our study suggests a relation among yeast presence and a decrease in oral health, once halitosis is one of the alterations found in small animal extra-oral examinations when this cavity is illness-stricken. 


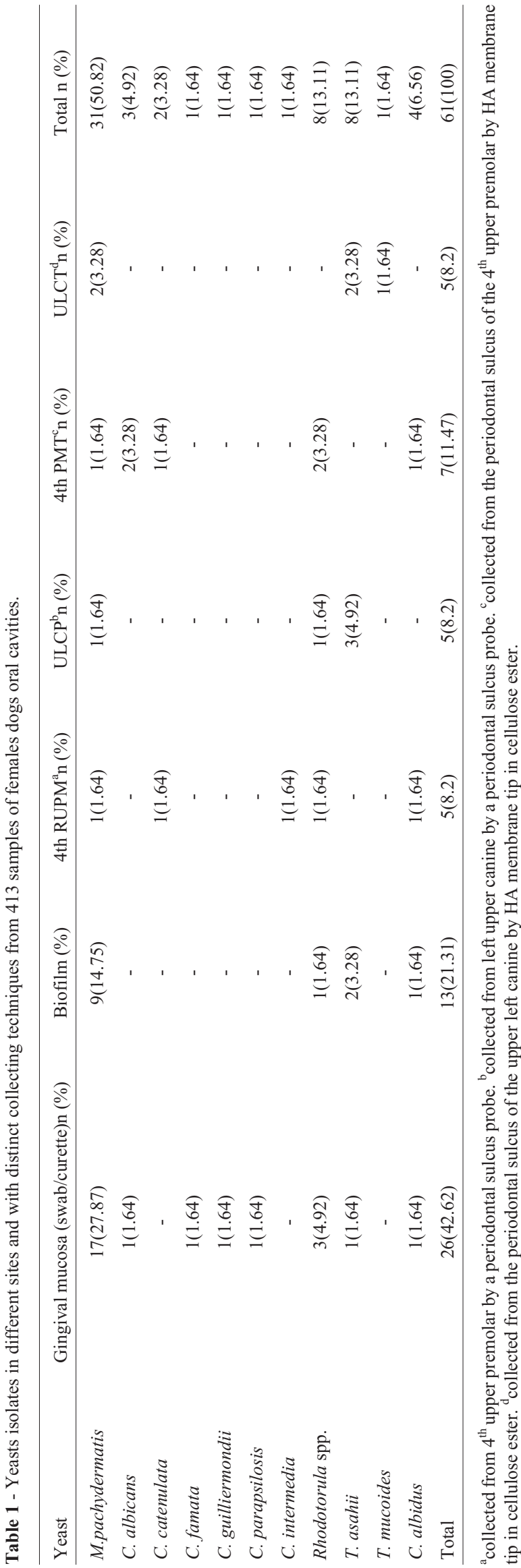

The sulcus average depth found in this study suggests that all animals had a healthy periodontium, presenting a sulcus depth within the normality range for dogs which correspond to $3 \mathrm{~mm}$ (Roza 2004; Mitchell 2005).

In this study, eleven different yeast species were isolated, whereas Brito et al. (2009) identified only four yeast species in the oral mucosa of dogs, including $M$. pachydermatis $(\mathrm{n}=69), C$. parapsilosis $(\mathrm{n}=4), C$. tropicalis $(\mathrm{n}=1)$ and $S$. cerevisae $(\mathrm{n}=1)$. Ours results are similar when only $M$. pachydermatis is considered. This yeast was isolated from all analyzed sites and in the different collection procedures $(50.82 \%)$, being the most frequently isolated yeast in the oral mucosa. Several authors have described M. pachydermatis as being part of the oral microbiota (Bond and Lloyd, 1997; Bond et al., 2000; Brito et al., 2009). However, Pinter and Noble (1998) mentioned a relation among oral diseases in dogs and this yeast in a stomatitis, pharyngitis and tonsillitis case. $M$. pachydermatis is the most widely studied yeast species in animals, and it is thought to make part of the microbiota of various anatomical sites, mainly the external ear and skin (Nobre et al., 1998; Bond et al., 2000; Cleff et al., 2005). However, Nobre et al. (1998) reported that at an imbalance condition between host and microorganisms occurs, this yeast can turns pathogenic due to a cell number increase referred to a predisposing factor.

The Candida genus, which represented $14.75 \%$ of the isolates in this study, is also considered to be part of the microbiota of animals (Ferreiro et al., 2002; Brito et al., 2009) and humans (Farah at al., 2000). C. albicans, isolated in three samples $(4.92 \%)$ is the main oral candidiasis pathogen in humans. In addition, other species such as $C$. tropicalis, C. parapsilosis, C. glabrata, C. krusei, C. lusitaniae, C. pseudotropicalis, C. guilliermondii and $C$. stellatoidea can also be involved (Farah at al., 2000). However, the low occurrence of $C$. albicans in this study shows that there are probably differences among oral human and canine yeast-like microbiota, as described by Hayashi et al. (2008). Stomatitis caused by C. albicans have been reported in four dogs (Jadhav and Pal, 2006); this was also the only species isolated from the oral mucosa of cats without oral lesions (Ferreiro et al., 2002). However, in recent studies, such as those by Hayashi et al. (2008) and Brito et al. (2009), this pathogen was not isolated from the oral mucosa of dogs. The specie C. parapsilosis was described by Brito et al. (2009) and also isolated in our study.

Species like C. catenulata, C. famata and $C$. intermedia have not been described yet as part of the oral microbiota of dogs. Radosavljevic et al. (1999) reported that this is a very important data since these yeasts have a pathogenic potential to develop systemic infections, especially in immunosuppressed patients.

Yeast isolation in the oral cavity of dogs suggests that these yeasts may be involved in oral pathologies, including dental biofilm formation. This information is supported by 
studies that demonstrated the ability of Candida species to the adherence and biofilm production (Gasparetto et al., 2005; López-Ribot 2005). In addition, a study by Canizzo et al. (2007) demonstrated the similar ability of $M$. pachydermatis isolated from dog ears to produce biofilm in materials such as polystyrene and polyurethane, which increase the survival rate of these yeasts.

The Rhodotorula genus identified in eight (13.11\%) isolates has already been described as an opportunistic agent, and is thought to be an emerging pathogen (Navarro et al., 2001). Rhodotorula spp. has already been isolated in animals as part of the microbiota of the external ear, oral cavity of dogs and the vaginal mucosa of healthy cats and canine females (Bornand 1992; Amaral et al., 1998; Braga et al., 2005; Cleff et al., 2007). However, this yeast was never associated with oral diseases nor in animals neither in humans.

In this study, $T$. asahii was isolated from eight (13.11\%) oral cavity samples. Shareef et al. (2008) described a human glossitis case associated to this yeast. The Trichosporon genus has also been isolated from the bronchoalveolar lavage of healthy dogs (Melchert et al., 2008) and from the external ear of healthy cats (Amaral et al., 1998). Trichosporose cases have been reported in cats (Greene et al., 1985; Doster et al., 1987).

From the Cryptococcus genus, C. neoformans is the main pathogenic specie (Mitchell and Perfect, 1995). In this study, C. albidus was isolated from all analyzed sites in one healthy animal (3.22\%) only, which demonstrates that this yeast was probably present in these sites transiently. This species is encapsulated and thought to be saprophytic, but it is rarely associated to clinical cases, although it has been isolated in system infection cases and pyelonephritis in dogs (Newman et al., 2003; Labrecque et al., 2005; Kano et al., 2008).

Malassezia pachydermatis, Candida spp., Rhodotorula spp. and Trichosporon asahii yeasts make part of the microbiota in the different sites of the oral cavity of the females dogs studied, being present without causing alterations. Yeast isolation was significantly more frequent in halitosis-bearing animals, which suggest some role of these microorganisms in the decrease of oral health.

\section{Acknowledgments}

This work was supported by Conselho Nacional de Desenvolvimento Científico e Tecnológico (CNPq), Coordenação de Aperfeiçoamento de Pessoal de Nível Superior (CAPES) and Fundação de Amparo à Pesquisa do Rio Grande do Sul (FAPERGS). Thanks to Hospital de Clínicas Veterinária (HCV/UFPel), extension project "Veterinária e a Saúde Ambiental Urbana: Ação para Controle Populacional de Cães no Município de Pelotas" and to Laboratório de Micologia - Hospital Santa Rita da Santa Casa de Porto Alegre/RS.

\section{References}

Amaral RC, Ibañez JF, Mamizuka EM, Gambale W, Paula CR, Larsson CE (1998) Microbiota indígena do meato acústico externo de gatos hígidos. Cienc Rural 28:441-445.

Bond R, Lamport AI, Lloyd DH (2000) Colonisation status of Malassezia pachydermatis on the hair and in the hair follicle of healthy beagle dogs. Res Vet Sci 68:291-293.

Bond R, Lloyd DH (1997) Skin and mucosal populations of Malassezia pachydermatis in healthy and seborrhoeic Basset Hounds. Vet Dermatol 8:101-106.

Bond R, Saijonmaa-Koulumies LEM, Lloyd DH (1995) Population size and frequency de Malassezia pachydermatis at skin and mucosal sites on healthy dogs. J Small Anim Pract $36: 147-150$

Bornand V (1992) Bactériologie et mycologie de l'otite externe du chien. Schweiz Arch Tierheilk 13:1-8.

Braga CAB, Resende CMF, Pestana ACNR, Carmo LS, Costa JE, Silva LAFS, Assis LN, Lima LA, Farias LM, Carvalho MAR (2005) Isolamento e identificação da microbiota periodontal de cães da raça Pastor Alemão. Cienc Rural 35:385-390.

Brito EHS, Fontenelle ROS, Brilhante RSN, Cordeiro RA, Monteiro AJ, Sidrim JJC, Rocha MFG (2009) The anatomical distribuition and antimicrobial susceptibility of yeast species isolated from healthy dogs. Vet J 182:320-326.

Canizzo FT, Eraso E, Ezkurra PA, Villar-Vidal M, Bollo E, Castellá G, Cabañes FJ, Vidotto V, Quindós G (2007) Biofilm development by clinical isolates of Malassezia pachydermatis. Med Mycol 45:357-361.

Cleff MB, Lima AP, Faria RO, Meinerz ARM, Antunes TA, Araújo FB, Nascente PS, Nobre MO, Meireles MCA (2005) Isolation of Candida spp from vaginal microbiota of healthy canine females during estrous cycle. Braz J Microbiol 36:201-204

Cleff MB, Xavier MO, Martins AA, Santin R, Meireles MCA (2007) Caracterizatión de la microbiota levaduriforme residente en la vagina de perras en diferentes fases del ciclo estral. Arch Med Vet 39:153-158.

Doster AR, Erickson ED, Chandler FW (1987) Trichosporonosis in two cats. J Am Vet Med Assoc 190:1184-1186.

Farah CS, Ashman RB, Challacombe SJ (2000) Oral candidosis. Clin Dermatol 18:553-562.

Ferreiro L, Moreira Jr JPR, Appelt CE, Berg V, Oliveira IA, Muschner AC, Reischak D, Chermette R (2002) Associações entre o isolamento de Candida albicans com a infecção pelo vírus da leucemia felina (felv), tratamentos com corticosteróides ou antimicrobianos em gatos. Acta Scientiae Veterinariae 30:179-183.

Gasparetto A, Negri MFN, Paula CR, Svidzinski TIE (2005) Produção de biofilme por leveduras isoladas de cavidade bucal de usuários de prótese dentária. Acta Scientiarum Health Sciences 27:37-40.

Greene CE, Miller DM, Blue JL (1985) Trichosporon infection in a cat. J Am Vet Med Assoc 187:946-948.

Hayashi K, Takada K, Hirasawa M (2008) Yeast-form fungi from dog oral cavity. IADR 86th General Session \& Exhibition. Microbiology/Immunology and Infection Control Program, http://iadr.confex.com/iadr/2008Toronto/techprogram/abstract_105472.htm.

Jadhav VJ, Pal M (2006) Canine mycotic stomatitis due to Candida albicans. Rev Iberoam Micol 23:233-234. 
Kano R, Katagawat M, Oota S, Oosumi T, Murakami Y, Tokuriki M, Hasegawa A (2008) First case of feline systemic Cryptococcus albidus infection. Med Mycol 46:75-77.

Labrecque O, Sylvestre D, Messier S (2005) Systemic Cryptococcus albidus infection in a Doberman Pinscher. J Vet Diagn Invest 17:598-600.

López-Ribot JL (2005) Candida albicans biofilms: More than filamentation. Curr Biol 15:453-455.

Melchert A, Motta YP, Giuffrida R, Laposy CB (2008) Avaliação citológica e microbiológica do lavado broncoalveolar em cães hígidos. Semina Ciências Agrárias 29:157-164.

Mitchell PQ (2005) Odontologia de Pequenos Animais. Roca, São Paulo, 175 pp.

Mitchell TG, Perfect JR (1995) Cryptococcosis in the era of AIDS- 100 Years after the discovery of Cryptococcus neoformans. Clin Microbiol Rev 8:515-548.

Navarro JT, Lauzurica R, Giménez M (2001) Rhodotorula rubra infection in a kidney transplant patient with pancytopenia. Haematologica 86:111.

Newman SJ, Langston CE, Scase TJ (2003) Cryptococcal pyelonephritis in a dog. J Am Vet Med Assoc 222:180-183.
Nobre MO, Meireles MCA, Gaspar LF, Pereira D, Schramm R, Schuch LF, Souza L, Souza L (1998) Malassezia pachydermatis e outros agentes infecciosos nas otites externas e dermatites em cães. Cienc Rural 28:447-452.

Pinter L, Noble WC (1998) Stomatitis, pharyngitis and tonsillitis caused by Malassezia pachydermatis in a dog. Vet Dermatol 9:257-261.

Radosavljevic M, Koenig H, Letscher-Bru V, Waller J, Maloisel F, Lioure B, Herbrecht R (1999) Candida catenulata fungemia in a cancer patient. J Clin Microbiol 37:475-477.

Roza MR (2004) Odontologia em Pequenos Animais. L.F. Livros de Veterinária, Rio de Janeiro, 361 pp.

Shareef BT, Harun A, Roziawati Y, Shaiful Bahari I, Deris ZZ, Ravichandran M (2008) Recurrent Trichosporon asahii Glossitis: A case report. J Contemp Dent Pract 9:114-120.

Trabulsi LR, Sampaio MC (2005) Microbiota ou flora normal do corpo humano. In: Trabulsi LR, Alterthum F (eds) Microbiologia. Atheneu, São Paulo, Brazil, pp 101-109.

All the content of the journal, except where otherwise noted, is licensed under a Creative Commons License CC BY-NC. 